\title{
Dynamic Capabilities in Small Firms: The Role of Practicing Accountants in Southern Africa
}

\author{
Garikayi Mutongoreya \\ Atlantic International University, Hawaii, USA \\ Email: garikaicolzim@gmail.com
}

How to cite this paper: Mutongoreya, G. (2021). Dynamic Capabilities in Small Firms: The Role of Practicing Accountants in Southern Africa. Open Journal of Business and Management, 9, 1671-1679.

https://doi.org/10.4236/ojbm.2021.94091

Received: April 30, 2021

Accepted: July 10, 2021

Published: July 13, 2021

Copyright $\odot 2021$ by author(s) and Scientific Research Publishing Inc. This work is licensed under the Creative Commons Attribution International License (CC BY 4.0).

http://creativecommons.org/licenses/by/4.0/

\begin{abstract}
The dramatic social changes have resulted in the need for SMMEs in South Africa to have dynamic capability and agile structures. However, due to the cost of hiring full time professional managers, certified public accountants or practicing accountants are required to fill this gap by offering dynamic capability and agility advisory services to their clients such as small firms so that they will be able to sense, seize opportunities and transform or reconfigure their products and service offering to remain viable and competitive in the fast-changing technological era.
\end{abstract}

\section{Keywords}

Dynamic Capability, Agility, Professional Accountants, Sense, Seize, Transform

\section{Introduction}

The Corona virus pandemic caught most SMMEs unprepared for long periods of lockdowns as they fell outside the essential services that were permitted to continue operating. In the Southern African context, there was confusion within the service sector on whether they were qualified to be regarded as essential services since they provide supporting services to almost all the sectors including those in essential services.

The small businesses which were mostly affected by the pandemic included, restaurant, lodges and travel firms, accounting and tax firms, lawyers, insurance services and brokers, call centers, IT support services, printing services. The official numbers of businesses affected by the pandemic are expected soon in the Southern Africa but experts were projecting closures of at least 60\% (OECD, 2020; Kassa \& Grace, 2020). 
However, in the United States, where studies and surveys on the impact of the pandemic on small and medium enterprises were already done, it was found out that the pandemic had caused huge disruptions among small businesses within few weeks after its onset and but before these businesses were granted the Coronavirus Aid, Relief, and Economic Security (CARES) Act (Bartik et al., 2020). The study posits that $43 \%$ of the small businesses surveyed had temporarily closed, and all these were attributed to the COVID-19. The same study found out that on average basis, $39 \%$ of the surveyed small and medium firms had reduced their active employment since January 2020 (Bartik et al., 2020).

In South Africa and most parts of America, the numbers of affected SMMES that temporarily closed and those that even failed to reopen is expected to be higher than the survey results for United States above because of the limited government relief aid given to SMMES affected by the pandemic and the lockdowns. We still await the official numbers from Stats SA on how many of such firms were affected and failed to reopen.

The dramatic social change such as COVID-19 pandemic was a wakeup call for Accountants in public practice servicing the SMME sector which was adversely affected. It is no longer business as usual for Accountants in practice as SMMEs now require dynamic capabilities to remain sustainable and the new normal being agile. The main reason is that they are in most circumstances are the only professionals that have an everyday relationship with the small business due to statutory requirements for companies to prepare annual financial statements in terms of international financial reporting standards (IFRS) as well as file statutory tax returns. Therefore, small business owners rely on the Accountants in public practice for such professional skills and other managerial skills. Dynamic capabilities will allow them to fine-tune their operating routines to the dynamic environmental requirements (Wilhelm et al., 2015).

The above dramatic social changes have increased the need for business to put in place dynamic capabilities to remain operational and viable, competitive, and sustainable. Dynamic capabilities are pivotal for businesses to constantly match their operating routines to this volatility (Laaksonen \& Peltoniemi, 2018; Teece et al., 2016; Wilhelm et al., 2015). Dynamic capabilities are however not likely to benefit and enhance the operating routines of all companies equally. Some companies have their operating routines enhanced more than others (Ambrosini and Bowman, 2009).

It has however been established that business that operate in high dynamic environments often encounter substantial fluctuations in competitors, and changes in customer preferences and technological demands. This is typical in the IT industry and the cellphone industry where new features and functionality and speed are always enhanced.

Businesses therefore are required to seize opportunities that come in such competitive environment and therefore enhancing their operating-routine performance. The businesses should be sensitive to the ever-changing customer trends 
and avoid being laggards in understanding these volatile trends and out compete rivals. That is the crux of dynamic capabilities as allows companies to fine-tune their operating routines to the dynamic environmental requirements (Wilhelm et al., 2015).

Scholarship posits that dynamic capabilities increase the effectiveness of operating routines, irrespective of environmental changes. This is however different with the effect of dynamic capabilities on the efficiency of operating routines. Dynamic capabilities are positively related to increases in operating routine performance. The costs of the improvement capabilities will only pay off when environmental changes are high (Laaksonen \& Peltoniemi, 2018).

It is time for Certified Public Accountants to break new paradigms whilst balancing with the regulatory and compliance requirements. This article will briefly explore the dynamic capability paradigm, risk, and uncertainties as these are pivotal for SMMEs to constantly match operating routines to this volatility (Laaksonen \& Peltoniemi, 2018; Teece et al., 2016; Wilhelm et al., 2015, Ambrosini and Bowman, 2009).

\section{Managing Risk (Known Probabilities) and Managing under Deep Uncertainty ("Unknown Unknowns")}

Risk is connected to known or identified outcomes where the likelihood of reoccurrences is well computed whereas uncertainty is related to unknown unknowns (Teece et al., 2016). Managing uncertainty is more problematic and serious especially where the economy is innovative and dynamic. A typical example of managing risk is how financial planners and bankers attempt to mitigate the exchange rate risk through hedging using forward contracts (Teece et al., 2016).

Being uncertain will pose a challenge to doing the right things as the decision maker will be faced with unknown unknowns which cannot therefore be insurable because insurance protects against a known insurable event. Entrepreneurial management skills are required to manage how to do the right things under deep uncertainty. This was noted by William Janeway who argued that "the innovative economy...is soaked in unquantifiable uncertainty" (Teece et al., 2016) and thereby causing far reaching and wider implications to management.

Uncertainty is now a common business environmental phenomenon during the 4th industrial revolution as firms have constantly been caught unaware and unprepared for the changes in the economic environment. According to Teece et al., (2016) Janeway argued that:

"a market mechanism for hedging the sort of ontological uncertainty that thrives where entrepreneurial innovation meets emerging market opportunity has never existed, is unlikely to ever exist, and will not persist if someone is foolish enough to create it."

The increased demand for innovation and complexity under deep uncertainty requires advisory services from Accountants in public practice to be proactive on 
everyday business environments rather than relying on the "invisible hand" of the market (Teece et al., 2016). Small and medium firms usually lack the required managerial skills to sense the dynamic environment, therefore they would need skilled professional to advise them on these changes.

\section{Organizational Agility and Dynamic Capabilities}

The term organizational agility is often used synonymously with organizational flexibility. The term flexibility was defined by George Stigler, a noble laurate of the 1930s as the firm's ability to manage demand uncertainties (Teece et al., 2016). Dynamic capabilities framework is a concept that is used to understand agility and will assist managers in making good and quality decisions in situations of high degrees of innovations in the economy and dramatic social change (De la Sablonniere, 2017; Teece et al., 2016).

Dynamic capabilities govern how firms integrate, build, and reconfigures the internal and external abilities to address changes in the business environments (Teece et al., 2016). These capabilities are undergirded by the management and organizational competences for studying and shaping their environments and by developing models which address threats and opportunities resultant from the changes.

In this regard, dynamic capabilities entail the required capacity of the firm to be innovative to adapt to the changes and create favorable variations and differentiation for the benefit of its customers as well as surpass competitors (Wilhelm et al., 2015). The three main constructs of dynamic capabilities are as follows:

1) Sensing of unknown futures-these are activities that are focused towards scanning the environment and identifying relevant changes, threats, and opportunities.

2) Seizing - these are activities aimed at developing new methods and ways of responding to the observed environmental changes, threats, and opportunities.

3) Transforming - these are activities focused at reorganizing and continual renewal of existing operating routines.

Dynamic capabilities are not the same as organizational strategy formulation process, but they need to be aligned or compatible with the direction given by the business strategy. These two should work synchronously for dynamic capabilities to be effective. On the token, a good strategy should be coherent, consistent, and should accommodate the need for innovation to achieving competitive advantages. Both strategy formulation and dynamic capabilities need to be sequentially developed and implemented jointly (Teece et al., 2016).

While routines processes are important aspects of dynamic capabilities, it can be argued that strong capabilities are not based entirely on routine processes and rules as routines are argued to slow the process of change. Users become too relaxed, comfortable and contend with routines without exploring new dimensions. It therefore requires Certified Public Accountants to offer advisory services 
through creatively and innovative thinking, acting entrepreneurially, and, where necessary overriding routine processes (Teece et al., 2016).

The main problem is how managers will acquire the necessary knowledge and the requisite capabilities because these often scarce and a challenge to duplicate or copy. In few cases, knowledge and the routine capabilities are often sold, and firm then customize them to suit its requirements. However, in most cases, these must be developed by the firm itself rather than be bought (Teece et al., 2016). Such development will require management's entrepreneurial capabilities by making strategic decisions that develops, models, and deploys capabilities for the changes (Teece et al., 2016). This will result in innovative combinations of resources which are anchored on profitable "value-capture mechanisms".

\section{Ordinary Capabilities}

It is an injustice to explore the elements of dynamic capabilities without a comprehension of "ordinary" capabilities. Ordinary capabilities are known for their ability to produce and sale goods and services in a day-to-day phenomenon (Teece et al., 2016). Such capabilities are required by organization's daily operations, but the firm may not need to own these capabilities. Often, these are outsourced to avoid risks of owning such assets. Examples of ordinary capabilities that can be outsourced by certified public accountants includes the following:

1) On the cloud bookkeeping software outsourced to software companies

2) Online Annual Financial Accounting software

3) Online payroll and tax software outsourced annually to the best software available

4) Recruitment services outsourced to HR companies

5) Printing services and advertising services

6) Company secretarial services

Many organizations have moved away from an outright purchase of an accounting, tax and annual financial statement software to avoid quick redundancy and the need for constant upgrade at the cost of the owner. The best approach now requires the software companies themselves to be agile and offer the best solutions for the accounting firms which can also be customized to suit the small business clients for the certified public accountants.

However, to identify the above ordinary capabilities to outsource, it is critical for the certified public accounting firm to identify its core services. These services however vary from context to context due to the legislations of the country and the professional body of the public accountants. In South Africa, the two main professional accounting bodies in public practice are the South Africa Institute of Professional Accountants (SAIPA) and the South African Institute of Chartered Accountants (SAICA). These two bodies have the majority of their members in public practice. Their core services include the following:

1) Bookkeeping services

2) Compiling of annual financial statements 
3) Independent review engagements

4) Audits (only those registered with the Independent Regulatory Board for Auditors (IRBA)

5) Tax services

6) Secretarial services

7) Advisory services

The other professional bodies such as the Association of Chartered Certified Accountant (ACCA) and the Chartered Institute of Management Accountants (CIMA) are mostly employed as internal accountants for companies but are also permitted by the South African Companies Act 71 of 2008 to offer to the public the above services.

Ordinary capabilities also include the deployment of a firm's workforce or human capital, how they utilize their plant and machinery, their administrative and financial management routines. If organization's ordinary capabilities are strong then it may imply that the firm is also technical proficient and fit to be able to complete tasks at high degrees of proficiency.

Besides the firm growing geographically, ordinary capabilities will not lead the company to grow technologically. There is little or no advancement or enhancement in its product offering. The firm can however increase the number of its branches in different regions but offering the same services or goods. Organizations will however not be able to respond positively to the volatile technological environment which may be full of surprises. Knowledge underpinning ordinary capabilities is largely clear and it may eventually become monotonous. The ordinary capabilities levels can be calculated and measured for a specific job or using the standard and best practices as benchmarks (Teece et al., 2016).

Despite ordinary capabilities ubiquitously available and are easy to transfer. These should however not be dismissed as unimportant because there are many companies that fail to perform the ordinary capabilities besides being "ordinary". However, being excellent at the "ordinary" is not a path to prosperity as such capabilities are likely to be possessed by all the competitors (Teece et al., 2016).

\section{Agility and Strategy}

No matter how shrewdly management may be adapting to risk and uncertainty, these efforts become less useful if it ignores framing the dynamic capability approaches in sync to the organizational strategy. Strong dynamic capabilities are argued to facilitate an organization to take advantage on environmental opportunities that are brought by its volatility nature. However, these underlying agility concepts have opportunity costs and should only be pursued if it is worthwhile to do so. It must be a favorable strategic approach to follow because weak or poor strategic approaches and leadership will often result in compromised dynamic capabilities. Therefore, agility and strategy should always work in tandem to each other. 


\section{The Role of Practicing Accountants in Agility through Dynamic Capabilities of Small and Medium Enterprises in the South African Context}

The dynamic capabilities framework acknowledges that risk and uncertainty are different in the qualitative sense. SMMEs rely on Professional Accountants for advisory services as the small firms do not have the financial capacity to employ professional staff and managers to manage their organisations. Therefore, Professional Accountants are required to offer such advisory services that will allow the SMMEs to become dynamic capable and manage uncertainty.

Such advisory services will include the following two interdependent elements of a dynamically capable organization as follows:

1) Professional Accountant ought to be equipped with managerial skills to fully manage the operations the small and medium clients under their portfolio. This will entail a complete understanding of the SMMEs internal and external environments. The Practicing Accountant ought to have a comprehension of the company's products and services to the capacity of offering advisory services such as merging and recombining technologies.

The practicing public accountants are now required to consider themselves as internal management staff of the small and medium clients that they provide services. They are now supposed to go beyond the usual bookkeeping, tax, and compliance services. The advisory services should be recalibrated to match the small and medium enterprises in a dynamic environment.

2) Professional Accountants should be capable of advising the SMMEs on adaptable structures capable of being modified rapidly. They can achieve this through having networks with other professions or through outsourcing certain billable services. They can also do this through creating of a Professional Accountant consortium structure for the purpose of collaborations.

3) Professional Accounting bodies need to seriously have a relook at the bylaws relating to public advertising for public accountants. This is because most professional bodies forbid their members to advertise the cost of their services. However, with online shopping now being the new concept of buying and selling, it is difficult for prospective small and medium clients to proceed in engaging an Accountant in public practice online without meetings and subsequent correspondences. This defeats the purpose of quicker and easier online shopping. Professional accounting regulating bodies should come up with allowable online strategies approaches.

Professional Accountants are usually the only administrative profession that are retained on a monthly retainer by SMMEs in South African. Therefore, they are required to wear dynamic capability and agility lenses, well-resourced, and networked to be able to accomplish the required changes of sensing, seizing, and transforming to remain relevant in this volatile economic and technological environment.

Small firms usually do not have long hierarchical and chain of command struc- 
tures and therefore are in position create disruptive changes that can topple the rival business's models and market positions as they are quicker in sensing, seizing and be able to transform before the larger companies which follow many procedures to approve any transformation (Teece et al., 2016).

\section{Limitations of Study}

The concept of dynamic capability and agility has been an alien concept in the accounting profession. As a result, there was scarce literature to juxtapose this study. It is a matter which scholarship should explore especially in environments with institutional voids to determine how this concept can be applied. This research was aimed arouse an appetite by the accounting professional into this discourse as the role of certified public accountants is pivotal for the success of the SMME sector.

There is limited scholarship for dynamic capabilities in small and medium enterprises as this concept is still fairly new and predominantly within the large and multi-national companies (Scarpellini et al., 2020). More voices are required from different aspects within the small business sector which employs most employs of the developing word.

The full effect of COVID-19 pandemic on the small businesses in the Southern African context has not been accurately recorded as most countries are within various lockdown levels and different waves. The study could not obtain the accurate statistics of how many small businesses remained closed and how many have partially opened by end of March 2021. Scholarships is therefore is called for detailed survey studies of the impact of the COVID-19 to the SMMEs sector within developing countries.

\section{Conclusion}

Organizational agility has become a hyped approach in scholarship and practice due to persistent dramatic social changes such the COVID-19 pandemic. Agility should be a priority for SMMEs when faced with deep uncertainty which results in threats and opportunities. The financial performance of SMMEs and their going concern is under threat if they do not recognize the new normal within business ecosystem. Technological advancement has been on an overdrive in most sectors of economies to the extent that significant numbers of the labor force is at risk of being replaced by machinery and thereby this will see SMME sector to crumble, a sector which is estimated to be employing around $80 \%$ of the workforce in the developing world.

One such recent threat is within the construction sector where new 3D printing technologies are being introduced for the construction of buildings. These will replace many SMMEs that are often subcontracted by larger firms in various constructions works in Africa. The SMMEs using the advisory services of certified accountants and other outsourced professionals should sense, seize and reconfigure their services in line with these uncertainties that await them. 
The above is now a characteristic of the modern-day economy of the $4^{\text {th }}$ industrial revolution that is prone to volatility in technology and other business environments. Certified public accountants are pivotal in ensuring the survival of the SMME sector and should therefore be acquainted with such emerging scholarship so as to explore how their clients can transform their operations in line with the new demands and requirements of the modern economy.

\section{Conflicts of Interest}

The author declares no conflicts of interest regarding the publication of this paper.

\section{References}

Ambrosini, V., \& Bowman, C. (2009). What Are Dynamic Capabilities and Are They a Useful Construct in Strategic Management? International Journal of Management Reviews, 11, 29-49. https://doi.org/10.1111/j.1468-2370.2008.00251.x

Bartik, A. W., Bertrand, M., Cullen, Z., Glaeser, E. L., Luca, M., \& Stanton, C. (2020). The Impact of COVID-19 on Small Business Outcomes and Expectations. Proceedings of the National Academy of Sciences of the United States of America, 117, 17656-17666. https://doi.org/10.1073/pnas.2006991117

De la Sablonniere, R. (2017). Toward a Psychology of Social Change: A Typology of Social Change. Frontiers in Psychology, 8, 1-20. https://doi.org/10.3389/fpsyg.2017.00397

Kassa, M. D., \& Grace, J. M. (2020). Race against Death or Starvation? COVID-19 and Its Impact on African Populations. Public Health Reviews, 41, 30. https://doi.org/10.1186/s40985-020-00139-0

Laaksonen, O., \& Peltoniemi, M. (2018). The Essence of Dynamic Capabilities and Their Measurement. International Journal of Management Reviews, 20, 184-205. https://doi.org/10.1111/ijmr.12122

OECD (2020). Covid-19: SME Policy Responses (pp. 1-55). https://oecd.dam-broadcast.com/pm 7379 119 119680-di6h3qgi4x.pdf

Scarpellini, S., Marín-Vinuesa, L. M., Aranda-Usón, A., \& Portillo-Tarragona, P. (2020). Dynamic Capabilities and Environmental Accounting for the Circular Economy in Businesses. Sustainability Accounting, Management and Policy Journal, 11, 1129-1158. https://doi.org/10.1108/SAMPJ-04-2019-0150

Teece, D., Peteraf, M., \& Leih, S. (2016). Dynamic Capabilities and Organizational Agility: Risk, Uncertainty, and Strategy in the Innovation Economy. California Management Review, 58, 13-35. https://doi.org/10.1525/cmr.2016.58.4.13

Wilhelm, H., Schlömer, M., \& Maurer, I. (2015). How Dynamic Capabilities Affect the Effectiveness and Efficiency of Operating Routines under High and Low Levels of Environmental Dynamism. British Journal of Management, 26, 327-345.

https://doi.org/10.1111/1467-8551.12085 